\title{
Sabiedrības drošība
}

\author{
ALEKSANDRA KJAKSTE, SIGITA STRUBERGA
}

Sabiedrības drošība apskata apdraudējumus sabiedrības vai tās daḷu tradicionālajiem dzīvesveidiem, paražām, reliǵiskajām praksēm, etniskajām un nacionālajām īpatnībām. Sabiedrības drošỉbas dimensija pēdējā desmitgadē ir bijusi gan politiskajā, gan akadēmiskajā dienaskārtībā, tomēr līdz šim nav ticis veikts pètījums, kas l̦autu integrēt indivīdu identificētos draudus to identitātei kopējā Latvijas iedzīvotāju draudu uztveres skatījumā un vērtēt iespējamās cēloṇsakarības, kuras pastāv starp uztvertajiem draudiem un atbilstošām rīcībpolitikām kā atbildēm uz tiem. Šajā grāmatas nodaḷā identificēti tie sabiedrības draudu veidi, kurus Latvijas iedzìvotāji uzskata par nozīmīgiem, kā arī apskatīts, vai un kā vietējās pašvaldības reagē uz iedzīvotāju bažām par apdraudējumiem sabiedrības drošības dimensijā. Analīzes rezultātā secināts, ka Latvijas iedzìvotāji identificē draudus to unikālajai patībai un atzīst tos kā būtisku izaicinājumu savai drošībai. Visbiežāk tos satrauc imigrācija kā potenciālais apdraudējums viṇu subjektīvā vērtējumā. Kopumā Latvijas sabiedrība tiek raksturota kā slēgta, uz tradicionālām vērtībām orientēta. Savukārt reǵionos iedzìvotāji izjūt plaisu starp reǵionu un galvaspilsētu un uzsver, ka pastāv atsevišķa, nošķirta dzìve un dienaskārtība un līdz ar to divas atšķirīgas kopienas. Rezultātā kā nozīmīgākos iekšējos apdraudējuma avotus sabiedrības drošības sektorā Latvijas iedzīvotāji nosaukuši citus iedzīvotājus vai to grupas, kā arī valsts pārvaldes iestādes. Savukārt pašvaldības bauda lielāku uzticēšanos. Kā ārējais apdraudējuma avots galvenokārt minēta Krievijas Federācija. Pašvaldību darbỉbas analīze liecina, ka kopumā pašvaldības reti un ierobežotā apjomā saredz savu lomu drošîbas stiprināšanā sabiedrības drošības sektorā. No iegūtajiem rezultātiem secināms, ka sabiedrības pārstāvju, kā arī pašvaldību darbinieku iesaiste plašākās diskusijās par drošỉbu, pilsonisko audzināšanu un iekḷaušanu ir būtisks faktors sabiedrības drošības stiprināšanā ar noteikumu, ka šāda veida aktivitātes būtu domātas visu sabiedrības grupu iekḷaušanai, nevis kādas grupas izslēgšanai, identitātes apdraudēšanai vai tās nozīmīguma noliegšanai.

Atslēgvārdi: sabiedrības drošỉba; identitāte; izslēgšana; imigrācija; kopiena. 
Societal security addresses threats to the traditional lifestyles, customs, religious practices, and ethnic and national characteristics of a society or part of it. The dimension of societal security has been on the political and academic agenda for the last decade, but so far, no research has been conducted to integrate the threats identified by individuals into their overall view on the threat perception of Latvia's population and to assess the possible causal link between the perceived threats and policy-making processes that respond to them. This section of the book identifies those types of societal threats that inhabitants of Latvia consider significant and explores whether and how local governments respond to inhabitants' concerns about threats to societal security. The analysis demonstrates that the inhabitants of Latvia identify threats to their unique identity and recognise them as a significant challenge. In general, Latvian society is characterised as closed and oriented towards traditional values. In the regions, on the other hand, people feel a gap between the capital city and their concerns, emphasising the disparity in lives and agendas, and thus - the existence of two different communities. As a result, inhabitants of Latvia have named other residents and groups, as well as national public administration institutions, as the most significant internal sources of threat when it comes to the dimension of societal security. Municipalities, on the other hand, enjoy greater trust. The Russian Federation is mainly mentioned as an external source of societal threats. In general, analysis of the activities of local governments demonstrates that they rarely (and to a limited extent) see their role in strengthening security in the societal security sector. It can be concluded from the obtained results that the involvement of public and municipal representatives in wider discussions on security, civic education, and inclusion is an important factor in strengthening societal security. Such discussions should involve all societal groups, should not exclude any group (even if their identity is perceived as threatening), and should not deny the significance of any group.

Keywords: societal security, identity, exclusion, immigration, community.

\section{levads}

Sabiedrības drošỉba apskata apdraudējumus sabiedrības vai tās daḷu tradicionālajiem dzīvesveidiem, paražām, relig̣iskajām praksēm, etniskajām un nacionālajām īpatnībām. Iepretī personiskajai drošībai, kur dominē cilvēka un valsts attiecības, sabiedriskā drošība raksturo attiecíbas starp dažādām sociālām grupām. Tātad uzmanības centrā ir sabiedrības vai atsevišḳu tās grupu identitātes izturētspēja, kas ḷauj sabiedrības drošǐbu interpretēt kā dienaskārtību, veidu, kā valsts tiek pārvaldīta sabiedrības tradicionālās patības saglabāšanai. N̦emot vērā Latvijas valsts vēsturisko pieredzi un šì briža izaicinājumus, sabiedrības drošỉba līdzās militārajai, politiskajai un ekonomiskajai drošîbai ir kḷuvusi par nozīmīgu dimensiju debatēs par Latvijas drošỉbu. Šāda pieeja 
ḷāvusi pakḷaut analīzei tos riskus un apdraudējumus, ko valsts sabiedrïbas grupas vai iedzīvotāiji kopumā identificē kā būtiskus to identitātei, kā arī integrēt tos plašākā redzējumā par pastāvošās sociālās struktūras noturīgumu attiecībā uz ārējiem un iekšējiem destabilizācijas mēóginājumiem.

Lai arī sabiedrības drošība pēdējā desmitgadē ir bijusi gan politiskajā, gan akadēmiskajā dienaskārtībā, līdz šim nav ticis veikts pētījumus, kas l̦autu integrēt indivīdu identificētos draudus to identitātei kopējā Latvijas iedzīvotāju draudu uztveres skatījumā un vērtēt iespējamo korelāciju, kas pastāv starp uztvertajiem draudiem un atbilstošām rīcībpolitikām kā atbildēm uz tiem. Tāpèc nodaļas mērḳis ir identificēt tos sabiedrïbas draudu veidus, ko Latvijas iedzīvotāji vērtē kā svarīgus. Vispirms tiks apskatīti līdz šim veiktie nozīmīgākie pētijumi par sabiedrības drošības sektoru. Tam sekos sabiedrības draudu operacionalizācija atbilstoši pētījuma vajadzībām, kā arī pētījuma rezultāti un secinājumi.

\section{Kas paveikts sabiedrības drošības izpētē?}

Latvijā drošības pētniecības jomā ir uzkrātas ievērojamas zināšanas par sabiedrības drošības dimensiju. Pēc neatkarības atjaunošanas tika izstrādāti vairāki pētijumi, kuru mērḳis bija sniegt paplašinātu izpratni par drošību, īpaši izcel̦ot cilvēkdrošības dimensiju, ${ }^{1}$ kas cita starpā skāra atsevišķ us ar identitāti saistītos jautājumus, ko iespējams plašāk vispārināt arī sabiedrības drošības aspektā. Tas nav pārsteidzoši, ņemot vērā Latvijas valsts vēsturisko mantojumu un mūsdienu aktuālos drošỉbas izaicinājumus.

Piemēram, 2003. g. Māras Sīmanes redakcijā tika izdots ANO pārskats par tautas attīstību "Latvija. Pārskats par tautas attīstību. Cilvēkdrošība 2002-2003” (Sīmane, M. (red.) (2003). Latvija. Pārskats par tautas attīstību. Cilvēkdrošîba 2002-2003. Rīga: ANO, 154 lpp. ISBN: 9984-684-19-9). Pārskatā uzmanība vērsta uz izpratnes par cilvēkdrošibu padziḷināšanu, apskatot Latvijas iedzīvotāju galveno bažu iemeslus un pakārtojot tos septiņiem cilvēkdrošibas aspektiem. 2012. g. Žanetas Ozolin̦as redakcijā tika publicēta monogrāfija "Cilvēkdrošība Latvijā un pasaulē: no idejas līdz praksei”, kuras mērḳis ir izstrādāt cilvēkdrošỉbas un drošībspējas teorētisko konceptu, kurš lietojams dažāda attīstības līmeņa valstīs un uz kura pamata radìt zināšanu kopumu par risinājumiem individuālā un nacionālā līmenī risku novēršanai un nedrošibas mazināšanai (Ozoliṇa, Ž. (red.) (2012). Cilvēkdrošỉba Latvijā un pasaulē: no idejas līdz praksei. Rīga: Zinātne, 8. lpp.). 2015. g. Žanetas Ozoliņas redakcijā tika publicēts pētījums "Dzimums un cilvēkdrošība: Baltijas jūras regiona skatījums" (Ozolina, Ž. (red.) (2015). Gender and Human Security: A View from the Baltic Sea Region. Riga: Zinātne, 272 lpp.), kas fokusējās ne tikai uz identificētiem riskiem un draudiem, bet arī uz sieviešu līdztiesības veicināšanu Baltijas jūras valstu reg̣ionā. Nozīmīgu ieguldījumu Latvijas drošîbas studiju pētniecībā sniedza arī 2019. g. aizstāvētā Riharda Bambala doktora disertācija "Cilvēkdrošỉba kā nacionālā interese ārpolitikā: Japānas, Kanādas un Norvēgijas gadījumu analīze”. Šis promocijas darbs līdztekus citiem pētījumiem sniedz paplašinātu izpratni par drošību, teoretizējot tādus jēdzienus kā cilvēkdrošỉba un dzīvotspēja/noturība (resilience). 
2016. gadā Žanetas Ozoliṇas redakcijā tika publicēta grāmata "Sabiedrības drošība. Iekḷaušanas - izslēgšanas dilemma. Krievvalodīgo kopienas portrets Latvijā" (Societal Security: Inclusion- Exclusion Dilemma. A portrait of Russian-speaking community in Latvia). Pētijuma mērḳis bija apskatìt tos potenciālos draudus un riskus, ko identificē Latvijas krievvalodīgo kopiena, un to, kā šie draudi un riski var veicināt drošỉbas sistēmas destabilizāciju valstī. No sabiedrības drošíbas perspektīvas šis pētījums sniedz vienas kopienas krievvalodīgo - subjektīvās drošỉbas uztveres atspogulıjumu.

Otrs pētījums, kurā aplūkota sabiedrības drošība Baltijas jūras regiona valstīs, ir 2018. gadā Mikas Āltolas (Mika Aaltola), Borisa Kuzṇecova, Andra Sprūda un Elizabetes Vizgunovas redakcijā publicētais kopdarbs "Sabiedrības drošỉba Baltijas jūras reǵionā: ekspertīzes kartēšana un rīcībpolitikas attīstîbas veicināšana" (Societal Security in the Baltic Sea Region: Expertise Mapping and Raising Policy Relevance). ${ }^{2}$ Tas apvieno autoru kolektīvu, kas sniedz skatijumu uz sabiedrības drošību Dānijā, Somijā, Islandē, Norvēǵijā, Zviedrijā, Igaunijā, Latvijā, Lietuvā, Polijā, Baltkrievijā un Krievijā.

Dažādi sabiedrības drošības aspekti Latvijas situācijas kontekstā daudz plašāk apskatīti dažādās sabiedriskās domas aptaujās. Apkopojot publicēto aptauju datus, iespējams noškịt trīs visbiežāk minētās draudu grupas iedzivotāju subjektīvajā sabiedrības draudu uztverē. Saskaņā ar tiem Latvijas sabiedrības subjektīvās drošības uztveres novērtējumā visbiežāk parādās jautājumi par nacionālo identitāti, reliǵisko identitāti un lingvistisko piederību, bet nedaudz retāk - par etnisko identitāti. Latviskās identitātes saglabāšanas indikators aptaujās tiek skatīts caur vairāku faktoru prizmu, piemēram, nāciju, tradīcijām un kultūru. Reliǵiskā brīvība tiek vērtēta kā gimenes atvērtỉba citu relig̣iju pārstāvjiem un viṇu religiiskajām praksēm. Savukārt etniskā patība kā sabiedrības drošỉbas garants aptaujās tiek skatīta, novērtējot attieksmes un orientāciju un biežāk reflektējot par lingvistisko, nevis šauri etnisko piederību.

Piemēram, saskaṇā ar SKDS 2019. gadā publicētiem datiem " $42 \%$ no respondentiem norādījuši satraukumu par to, ka norisinās latviešu kultūras amerikanizācija”’3. Turklāt, saskaṇā ar domnīcas Pew Research Center rīkotās 2018. gada aptaujas datiem, "38\% aptaujāto Latvijas iedzīvotāju pauduši uzskatu, ka viṇu nācijas kultūra ir ìpašāka nekā citas”’. Bet kā nozìmīgu faktoru

2 Aatola, M. et al. (2018). Societal Security in the Baltic Sea Region: Expertise Mapping and Raising Policy Relevance. Rīga: Latvijas Ārpolitikas institūts, p. 270.

3 Ziṇu ag̉entūra LETA (2019). Kultūras amerikanizācija Latvijas iedzīvotājus lielākoties nesatrauc. Pieejams: https://lat.bb.lv/raksts/sabiedriba/2019/07/07/kulturas-amerikanizacija-latvijas-iedzivotajus-lielakoties-nesatrauc

4 Pew Research Centre (2018). Eastern and Western Europeans Differ on Importance of Religion, Views of Minorities, and Key Social Issues. Pieejams: https://www.pewforum.org/2018/10/29/ 
identitātes saglabāšanā respondenti ir minējuši piederības sajūtu Latvijai: "71\% respondentu uzskatīja, ka, lai būtu īsti piederīgs Latvijai, te jāpiedzimst, bet $61 \%$ aptaujāto norādīja, ka gimenes saknēm ir jābūt no šĩs valsts"s.

Attiecībā uz apdraudējumiem reliǵiskajai piederībai šāda ievērojama subjektīvā draudu uztvere aptaujās nav novērojama, jo Latvijas iedzīvotāju pašidentifikācijai reliǵija nav tik nozīmīga. Saskaṇā ar Pew Research Center datiem tikai $10 \%$ Latvijas iedzīvotāju reliǵija ir ļoti svarīga vinuu dzīvē, lai gan $71 \%$ respondentu atzinuši, ka tic Dievam. ${ }^{6}$ Vienlaikus Latvijas sabiedrība raksturojama kā konservatīva un noslēgta, ar ierobežotu spēju pieņemt citu reliǵiju pārstāvjus: "19\% respondentu būtu gatavi pien̦emt ǵimenē musulmani un 53\% - ebreju”.

Apdraudējums lingvistiskajai patībai Latvijas publiskajā dienaskārtībā ir viens no visbiežāk aktualizētajiem sabiedriskās drošības draudiem. İpaši tiek izcelta plaisa starp latviešu un krievu valodā runājošiem, uzsverot sabiedrības sašḳeltību divās lingvistiski atškirīgās kopienās. Lai arī šis aspekts dažkārt gan apzināti, gan neapzināti tiek jaukts ar etnisko piederību, tomēr tas ir stingri nošķirams.

Runājot par iedzīvotāju subjektīvo drošỉbas uztveri saistībā ar etnisko piederību, aptauju dati parāda divas nozīmīgas tendences. Saskaņā ar Pew Research Center 2018. gada datiem, $61 \%$ etnisko krievu un 45\% pārējo aptaujāto Latvijas iedzīvotāju uzskata, ka ir labāk, ja sabiedrību veido cilvēki ar dažādu nacionālu un kultūras piederību. ${ }^{8}$ Tas liecina, ka aptuveni puse Latvijas iedzīvotāju ir gatavi dzìvot heterogēnā sabiedrībā, bet "24\% respondentu, kas sevi ir uzskatījuši par etniskiem krieviem, neidentificē sevi ar valsti, kurā tie dzīvo"'.

Līdzīgas tendences uzrāda pētījumi, kas pievērsušies krievvalodīgo kopienas uzskatu analīzei. No tiem secināma ne tikai lielas šo iedzīvotāju daļas atsvešinātība no pastāvošās politiskās sistēmas, bet arī ciešas saiknes izjūta ar Krievijas Federāciju. Piemēram, taujāti, vai Krievijai būtu pienākums aizsargāt krievvalodīgo intereses un tiesības Latvijā, tie atbildējuši apstiprinoši. ${ }^{10}$ Šādas nostājas ievērojamā daļā Latvijas sabiedrības negatīvi ietekmē sabiedrības drošîbu, kā arī potenciāli var kḷūt par iemeslu politiskās drošības situācijas pasliktināšanai.

eastern-and-western-europeans-differ-on-importance-of-religion-views-of-minorities-andkey-social-issues/?fbclid=IwAR0Af1zqir6iRYBAYd_dZ1hsDOoMOhMJUc4qxgpqD6Q6XdDF4ZulqXUlLp4\#fn-30843-1

5 Ibid.

6 Ibid.

7 Ibid.

8 Pew Research Centre (2017). Ethnic Russians in some former Soviet republics feel a close connection to Russia. Pieejams: http://www.pewresearch.org/fact-tank/2017/07/24/ethnic-russians-in-some-former-soviet-republics-feel-a-close-connection-to-russia/

9 Ibid.

10 Ibid. 


\section{Sabiedrības drošības jēdziens}

Sabiedrïbas drošỉbas (societal security) konceptu 20. gadsimta 80. gados ieviesis viens no spilgtākajiem Kopenhāgenas skolas (Copenhagen School) pārstāvjiem Barijs Buzans (Barry Buzan). Savā darbā "Cilvēki, valstis un bailes" (People, States \& Fear: The National Security Problem in International Relations) Buzans, paužot uzskatu, ka "mūsdienu drošîbas izpratni veido ne tikai militārā drošība, bet arī (indivīdu) politiskā, ekonomiskā, ekolog̣iskā un sabiedrības (kopienas) drošîba"11. Tādējādi viņš kḷuva par vienu no pirmajiem pētniekiem, kas paplašināja drošỉbas uztveri no valsts līmeṇa līdz sabiedrības un indivīda līmenim. ${ }^{12}$

Barija Buzana izpratnē sabiedrības drošība nozīmē sabiedrības tradicionālo valodas un kultūras modeḷu, tradīciju, relig̣iskās un etniskās identitātes ilgtspēju un piel̦aujamo attīstîbas nosacỉjumu nodrošinājumu un ilgtspēju. ${ }^{13}$ No tā secināms, ka sabiedrības drošỉba ir stāvoklis, kurā netiek apdraudēta sabiedrības ilgtspēja, valoda, kultūra un indivīdu reliǵiskā un etniskā identitāte un tiek uzsvērta sabiedrības kā vienotas kopienas pastāvēšana. Praksē tas nozīmē uzskatu, ka indivīdu un sabiedrības drošìba ir atkarīga ne tikai no valsts spējām nosargāt teritoriju un kopienu no ārējiem draudiem. Barijs Buzans pieņēma, ka indivīdu un sabiedrības drošîbu var apdraudēt arī iekšêjie draudi. Tā sabiedrības drošîbu Buzans saistīja ar piel̦aujamiem nosacījumiem tradicionālu, sabiedrībai raksturīgu dzīvesveidu, kultūras, valodas un citu identitātes ipatnibu saglabāšanai.

Paplašinot Barija Buzana izvirzītās tēzes par sabiedrības drošības definējumu, 1993. gadā Oles Vēvera (Ole Wrever) redakcijā tika publicēts pētījums "Identitāte, migrācija un jaunā drošības dienaskārtība Eiropā" (Identity, Migration and the New Security Agenda in Europe), kurā tika rekonceptualizētas Buzana idejas par drošības uztveres paplašināšanu. Saskaņā ar šì pētījuma autoru atzin̄ām sabiedrības drošība ir neatñemama valsts drošības sastāvdaļa. "Ja valsts drošības garants ir suverenitāte (zaudējot suverenitāti, valsts neizdzīvos kā valsts (struktūras ziņā)), tad sabiedrības drošỉbas garants ir identitāte (zaudējot identitāti, sabiedrība neizdzīvos)." ${ }^{4}$ Tādējādi arī Vēvers, līdzịgi kā

11 Buzan, B. (1983). People, States \& Fear: The National Security Problem in International Relations. London: Wheatsheaf Books, p. 10.

12 Ibid., p. 33.

13 Buzan, B. (1991). People, States and Fear: An Agenda for International Security Studies in the PostCold War Era (2nd ed.). London: Harvester Wheatsheaf, p. 123.

14 Weawer, O. et al. (1993). Identity, Migration and the New Security Agenda in Europe. London: Pinter, p. 23. 
Buzans, sabiedrības drošību sākotnēji drīzāk skatīja nacionālās drošības paplašinātā perspektīiā.

Ole Vēvers uzsvēris: lai gan sabiedrības drošỉba ir cieši saistìta ar politisko drošību, kas ir par valsts pārvaldes organizacionālo, legitimitātes un ideologisko stabilitāti, tomēr tā ir nošķirama kā atsevišķa vienība. Lìdzīgi kā Buzans, viņš uzsvēris identitātes saglabāšanas nozīmi un piedāvājis šādu sabiedrības drošỉbas definīciju: "sabiedrības drošība ir definējama kā identitātes aizsardzība pret uztvertiem draudiem vai, precīzāk, kopienas aizsardzība pret tās uztvertiem draudiem identitātei"15. Šādā koncentrētā definīijā Vēvers iekḷauj plašu identitātes dimensiju klāstu. Viņš uzskata, ka tas skar bailes par kultūras īpatnību saglabāšanu, kopienas, nācijas, reliǵijas, dzimuma tradicionālo uzvedības modelıu un citu līdzīgu individuālo, grupu un visas sabiedrības skatījumu uz savas identitātes ilgtspēju. ${ }^{16}$ Vienlaikus Ole Vēvers arī norādījis uz nepieciešamību diferencēt dažādu indivīdu grupu intereses vienā sabiedrībā, tādējādi pieḷaujot, ka noteiktos apstākḷ̆os tās var savstarpēji konfliktēt un radìt apdraudējumu cita citai.

Buzans, Vēvers un Vilde (1998) savā kopdarbā uzsvēruši, ka kopienas definē apdraudējumus to identitātei dažādos veidos, izceḷot trīs nozīmīgākās faktoru grupas, kas to ietekmē. Tās ir: migrācija, vertikālā sāncensība un horizontālā sāncensỉba. Autori piel̦auj, ka draudu avoti var būt gan iekšèji, gan ārēji, gan iepriekš plānoti un apzināti, gan strukturāli, gan arī neplānoti un neapzināti. Šādā skatijjumā imigranti tiek identificēti kā tādi, kam piemīt potenciāls mainīt sabiedrības izkārtojumu un kohēziju. Horizontālā sāncensība apskata tos draudus, kas potenciāli var rasties no blakām esošas kultūras dominances, un rezultātā var mainīties pastāvošā kultūra. Savukārt vertikālā sāncensība kā drauds tiek skatīta, ja izmaiņas sabiedrības kultūrā tiek projicētas "no augšas", lai mainītu sabiedrības pašidentifikāciju, integrējot to "pārnacionālos" identitātes projektos (piem., eiropeiskā identitāte, ES pilsonība u. tml.). ${ }^{17}$

Līdzīgs skatījums uz sabiedrības drošību ir arī, piemēram, Juliānam Čifu (Iulian Chifu). Viṇš sabiedrības drošỉbu skata kā visaptverošu jēdzienu, kas apkopo daudzveidīgus mūsdienīgos draudus sabiedrībai. Čifu ieskatā, kā nozīmīgi te apskatāmi sociālās identitātes un sociālās saliedētības nestabilitātes fenomeni. Viņš secina, ka sabiedrības drošības sektorā apskatāms viss, kas saistīts ar sabiedrības locekḷu identitātes un saliedētības/sadarbības saglabāšanu,

15 Wæver, O. (2008). The Changing Agenda of Societal Security. In: Brauch H. G. et al. (eds.) Globalization and Environmental Challenges. Hexagon Series on Human and Environmental Security and Peace. Springer, Berlin, Heidelberg. p. 581.

16 Ibid.

17 Buzan, B., Wæver, O., de Wilde, J. (1998). Security: A New Framework for Analysis. Lynne Rienner Publishers United Kingdom, pp. 239. 
ņemot vērā konkrētas sabiedrības īpatnības. ${ }^{18}$ No tā izriet, ka sabiedrības drošỉbas izpētē uzmanība tiek pievērsta tam, kā tiek nodrošināta sabiedrības un tās dalıu identitātes īpatnību, t. sk. valodas, kultūras, tradīciju, paražu, ilgtspēja. Par draudiem tie tiek uzskatīti tad, kad tie radušies valsts institūciju vai citu valsts iekšējo aktoru darbības rezultātā un apdraud sabiedrības dzìves ilgtspēju. Tādējādi mūsdienu sabiedrības drošības izpratne iekḷauj indivīdu drošības sajūtu (safety) gan attiecībā uz iekšējiem, gan ārējiem draudiem. ${ }^{19}$

Pētijuma analītiskā ietvara izveidei šìs nodal̦as izstrādē ņemti vērā ne tikai sabiedrības kopumā uztvertie draudi tās identitātei neatkarīgi no iedzīvotāju piederības pie kādas sabiedrības grupas, bet izcelti arī tie subjektīvi uztvertie apdraudējumi, kas attiecināmi uz minoritāšu grupu pārstāvjiem. Atbilstoši minētajam noteiktas šādas draudu grupas, kas saistītas ar sabiedrības drošību: grupas identitāte; izglīīiba; grupas pārstāvniecība (sabiedrības un politiskā līdzdalība); kultūra un reliǵija; izmaiṇas kopienas lielumā un ietekmes apjomā; rasisms un nacionālisms; vairākuma dominance (psiholog̣isks spiediens, iejaukšanās grupas iekšêjās lietās).

Lai analizētu pārvaldes spēju reagèt uz izaicinājumiem sabiedrības drošībai un apzinātu aktivitātes, kas vērstas uz Latvijas sabiedrības tradicionālās patības saglabāšanu, izmantota labas pārvaldības rādītāju matrica, kas iekḷauj šādus rādītājus: pārvaldības sistēmas stabilitāte/prognozējamība/pēctecība; plānošanas ilgtermiņa pieeja - ilgtermiņa redzējums; reformu jēgpilnums - ieviešanas efektivitāte, caurskatāmība; normatīvo aktu izmaiṇas; ierēdṇu profesionalitāte; informētība, kā rīkoties X stundā; preventīvās rīcībpolitikas veidošana; iestāžu koordinācija.

Piedāvātās matricas aizpildīšanai katrā sabiedrības draudu grupā tika izvēlēti jautājumi intervijām ar vietējo pašvaldību pārstāvjiem. Tie palīdzēja noskaidrot vietējo pašpārvalžu pārstāvju informētību par iedzìvotāju bažām un uztvertajiem draudiem identitātei, ar ko tie saskaras savā ikdienā. Pēc tam tika apskatītas analizējamo pašvaldību realizētās aktivitātes sabiedrības drošības draudu novēršanai. Šāda pieeja sniedza iespēju izcelt gan tos faktorus, kas tieši saistīti ar apdraudējuma radīšanu sabiedrības drošībai un kas pastāvīgi negatīvi ietekmē drošības sajūtu, gan arī netiešos jeb fona rādītājus, kas ir saistīti ar drošỉbas vidi un kas var potenciāli negatīi ietekmēt personas drošības uztveri un veicināt tās neapmierinātību un diskomfortu (piem., normatīvo aktu izmaiņu biežums vai ierēdṇu profesionalitātes līmenis).

18 pdfs/societal_security.pdf

19 Laegried, P., Rykkja, L. H. (ed.) (2019). Societal Security and Crisis Management. Governance Capacity and Legitimacy. London: Palgrave Macmillian, p. 5. 


\section{Latvijas iedzīvotāji par sabiedrības drošību}

Veiktās fokusa grupu intervijas atklāj, ka Latvijas iedzīvotāji draudus sabiedrības drošībai uztver kā nozīmīgus, tomēr ne prioritārus kopējā drošības redzējumā. Lai arī visās pašvaldībās apdraudējumi sabiedrības drošỉbai tika minēti, tomēr tikai trijās no divpadsmit - Aizkrauklē, Liepājā, Rēzeknē - iedzīvotāji tos nosauca starp trīs nozīmīgākajiem draudu veidiem. Nevienā pašvaldībā respondenti sabiedrības draudus neizcēla kā svarīgākos.

\section{Krievija}

Kā būtiskākais ārējais draudu avots sabiedrības drošībai visos reǵionos tika minēta Krievijas Federācija. Atsevišķās fokusa grupās, piemēram, Rīgā, respondenti nosauca iespējamo migrācijas vilni no musulmaṇu valstīm kā ievērojamu potenciālo apdraudējumu sabiedrības drošỉbai Latvijā. Visbiežāk tas tika asociēts ar svešu tradīciju un nepieņemamu reliğisko paražu ieviešanu, kas varētu negatīvi ietekmēt Latvijas iedzīvotāju tradicionālo dzīvesveidu. Vēl vienā pašvaldībā kā potenciāls apdraudējums tika minēta Ķīnas Tautas Republikas pilsoṇu vēlme nākotnē meklēt jaunas, brīvas teritorijas dzīvesvietu ierīkošanai. Šis un atsevišḳi citi naratīvi, kas iekḷauti iedzīvotāju pārdomās par apdraudējumiem to identitātei, norādīja uz bailēm no eiropeizācijas, globalizācijas un plašākas mijiedarbības ar starptautiski dominējošām kultūrām, t. sk., piemēram, no amerikanizācijas.

\section{Sabiedrības šḳelšana}

No iekšējiem draudu avotiem galvenokārt tika minēta sabiedrības šḳelšanās latviski runājošo un krievvalodīgo kopienās, kā arī atsevišķu iedzīvotāju grupu atsvešinātība no Latvijas valsts un naidīgums pret to. Reǵionos kā draudu avotus ne tikai politiskajai, bet arī sabiedrības drošỉbai respondenti atzīmēja reǵionālo reformu un depopulāciju lauku apvidos. Tika nosaukta arī Rīgas un Pierīgas iedzīvotāju arogantā attieksme pret "lauciniekiem” kā profesionālās, tā sadzīves jomās.

\section{Identitāte}

Pētījuma gaitā tika izgaismotas vairākas grupu identitātes, kuru kontekstā iespējams runāt par iedzīvotāju subjektīvo draudu izjūtu. Kā nozīmīgākā minama piederība latviešu vai krievvalodīgo lingvistiskai kopienai. Piederība latviešu valodā runājošai kopienai vairumā gadījumu pārklājas arī ar etnisko piederību, bet krievvalodīgo grupas gadījumā šāda pārklāšanās nav tik izteikta. Zīmīgi, ka latviešu valodā runājošie fokusa grupu interviju dalībnieki 
izteica vienlīdz lielas bažas par apdraudējumiem to etniskajai identitātei un valodai kā krievvalodīgie iedzīvotāii.

Šis un arī citi pētījumi atklāj, ka plaisa starp latviešu un krievvalodīgo kopienu galvenokārt ir aktuāla grupu un plašākā sabiedrības līmenī, bet ne indivīdu līmenī. Tomēr dažkārt tika izteiktas bažas par abu kopienu pārstāvju līdzāspastāvēšanu bez konflikta individuālā līmenī.

Sieviete darbspējas vecumā, Talsi: Ja divas tautības satiekas gimenes dzīvei, tad tie ir potenciālie psihoterapeita pacienti, jo ir ḷoti grūti savienot šìs abas atšķirīgas mentalitātes.

Nesaskaņu pamatcēlonis latviešu respondentu skatijumā galvenokārt ir vēsturiskā pieredze.

Respondente, Talsi: Mums nekas nav pret cittautiešiem, mums vienkārši ir rūgta pieredze par tiem cittautiešiem, kas ir gājuši pie mums un mācījuši, kā mums dzīvot. ${ }^{20}$ Tãpēc ir grūti pieñemt, ka krievi ir labi Latvijā.

Savukārt krievvalodīgo kopienas pārstāvji atsevišķās fokusa grupas intervijās norādījuši uz aizspriedumiem, kas, viṇuprāt, pastāv latviešu vidū. Pamatā aizspriedumi ir par valodas zināšanām, piederības izjūtu valstij un patriotismu.

Jauniete, Daugavpils: Ir stereotips, ka, ja tu dzìvo Daugavpilī, tad automātiski nezināsi valodu, bet tā nav.

Abu lingvistisko kopienu gadījumos arī tika minēti atsevišş̧i piemēri par indivīda subjektīvi uztvertu diskrimināciju uz etniskās piederības pamata.

Sieviete darbspējas vecumā, Rēzekne: .. man ir krievu vārds un uzvārds, es pati jūtos kà latviete, bet, mācoties Rīgā, viena pasniedzēja mani ienīda tikai par to, ka man ir krievu vārds un uzvārds. [.] Ja tu strādà valsts amatā - tavs vārds un uzvārds spēlē l̦oti lielu lomu. Ja tevi sauc Ivans Ivanovs, tev nedos augstu amatu.

Secināms, ka abu lingvistisko kopienu pārstāvjiem ir raksturīgas negatīvas emocijas, kas dažkārt ir saistītas arī ar apdraudējuma sajūtu no citas kopienas pārstāvju puses. Tas zināmā mērā skaidrojams ar sabiedrības drošības dilemmas izpratni. ${ }^{21}$ Tomēr drīzāk šādas bažas nav saistāmas ar izteiktām bailēm vai sajūtu par tūlītēju apdraudējumu. Latviešu kopienas pārstāvji ar bažām

21 Plašāk skatît: Societal Security: Inclusion-Exclusion Dilemma. A portrait of Russian-speaking community in Latvia (2016). Ed. Ozoliṇa, Ž. Rīga: Zinātne. 
raugās uz krievvalodīgo kopienas pārstāvju attieksmi pret šo valsti iespējamo uzvedību krīzes situācijās.

Pensionēts vīrietis, Talsi: Talsu krieviem ir loti liels naids pret pastāvošo valdību, Latviju. [..] Viņi redz tā - ak, nolādètā Latvija!

Krievvalodīgo kopienas pārstāvji drīzāk ar aizvainojumu raugās uz, viņuprāt, nevienlīdzīgu attieksmi un vairākuma dominanci. İpaši šis aizvainojums atainojas ne tik daudz attieksmē pret latviešu kopienu, cik pret pastāvošo politisko režīmu, skatot to kā drīzāk naidīgu. Rezultātā secināms, ka krievvalodīgo kopienas pārstāvjiem raksturīga apdraudējuma un psiholog̣iska spiediena subjektīva uztvere, kas būtiski ierobežo šìs sabiedrības daḷas iekḷaušanās procesu.

Ar nacionālo identitāti šajā pētījumā tika izprasta Latvijas sabiedrība kā vienotas kopienas patība un iedzīvotāju subjektīvi uztvertie draudi pret Latvijas sabiedrību kopumā. Citu reliǵisko, etnisko vai citas identitātes grupas pārstāvju iekḷaušana Latvijas sabiedrībā ir sarežğìts un izaicinošs process, jo struktūras ziṇā Latvijas sabiedrība tiek raksturota kā slēgta sabiedrība. Daudzi Latvijas iedzīvotāji citu reliǵisko, etnisko vai citu identitāšu pārstāvju iekḷaušanu sabiedrībā saskata kā apdraudējumu savai identitātei.

Fokusa grupas intervijas dalïbnieks, Talsi: Citu reliǵisko pārstāvju pieņemšana savā ǵimenē ir lototi sarežğìta. Ar lielu sajūsmu es to neuztvēru.

Tiesa, reǵionos aptaujātie iedzīvotāji biežāk ārvalstnieku klātbūtni skata kā potenciālu apdraudējumu sabiedrības drošībai nākotnē, kamēr Rīgā, viņuprāt, tā jau ir būtiska problēma.

Respondents, Daugavpils: Imigranti mums nav problèma. Mès viniem esam lauki. Ja nu kāds cilvēks parādās, tad tā nav problèma. Jā, Rīgā gan ir grüti pat nopirkt kebabu, ja tu nezini anglu valodu, bet pie mums nē.

Izṇēmums šajā ziņā bija respondenti fokusa grupā Jaunjelgavā, kuri intervijas laikā norādīja, ka, viņuprāt, patvēruma meklētāji no musulmaṇu valstīm ir reāls šĩ brīža apdraudējums nacionālai un kultūras identitātei un ka Latvija nav gatava stāties pretim šim izaicinājumam. Savukārt Rīgā kāds respondents uzskatīja, ka, viṇa ieskatā, nākamās paaudzes pārstāvji reageēs asāk uz imigrantiem un "noliks viņus pie vietas".

Rīgā notikušu fokusa grupu interviju rezultāti apliecināja, ka iedzīvotāji imigrantu klātbūtni saskata kā draudu. İpaši tas attiecināms uz ieceḷotājiem no musulmaņu valstīm. Plašāka musulmaņu klātbūtne vai, piemēram, iespējama mošeju parādīšanās Rīgā, fokusa grupu interviju dalībnieku ieskatā, negatīvi ietekmētu Latvijai raksturīgās kultūrtelpas ìpatnības. Respondenti interviju 
laikā norādīja uz nopietnām bailēm par Latvijas nācijas izdzīvošanu gadījumā, ja tā pārdzīvotu ievērojamu musulmaṇu imigrācijas vilni. Tāpēc ES patvēruma politika tika interpretēta galvenokārt negatīvi. Zīmīgi, ka iedzīvotāju izglìtības līmenis vai cel̦ošanas biežums nekorelē ar aizspriedumu mazināšanos pret ieceḷotājiem.

Kā nozīmīgākos draudus šajā sakarā aptaujātie Latvijas iedzīvotāji minēja tradicionālajam dzīvesveidam svešu vērtību ienākšanu un svešu uzskatu paušanu. Šāda veida apdraudētības sajūta īpaši raksturīga vecāko paaudžu pārstāvjiem. Piemēram, šajā sakarā bažas rada draudi tradicionālam gimenes institūtam.

Pensionāre, Ādaži: Nopietnu nedrošību rada giimenes institūcijas graušana ar visādu praidu ${ }^{22}$ aț̦aušanu.

Līdzīgi vecākās paaudzes pārstāvju uzskati atainojušies arī, kad runa ir par kultūras amerikanizāciju un Rietumu popkultūras dominanci. Izteikti gados vecāko cilvēku vidū novērojama arī nedrošība, kas tiek izjusta, vienkārši sastopoties ar citu nacionalitāšu pārstāvjiem.

Jauniete, Rēzekne: .. manai paaudzei problēmu nav. Bet manam tētim ir aizspriedumi pret citām nacionalitätēm. Vecāki cilvēki nesaprot, ka mès visi esam vienādi.

Jaunieši atzīst, ka svešu kultūru pārstāvji, atšḳirīgas ādas krāsas vai Latvijas sabiedrībai svešas etniskās piederības pārstāvji var tikt un tiek diskriminēti. Jauno cilvēku ieskatā, zemais tolerances līmenis ir saistīts galvenokārt ar vēsturisko mantojumu, vājām zināšanām par citām kultūrām un līdz šim nenotikušu plašu mijiedarbību ar citu kultūru pārstāvjiem, īpaši lauku reǵionos.

\section{Patriotisms}

Cits aspekts, ko saistībā ar nacionālās identitātes problemātiku identificējuši aptaujātie Latvijas iedzīvotāji, ir patriotisma trūkums sabiedrībā. Piemēram, Rēzeknē fokusa grupas dalībnieki norādīja, ka šis ir patiesi nopietns izaicinājums, ar ko sastopas Latvijas valsts. Rezultātā nacionālisms ir vairāk izteikta iezīme, bet patriotisma trūkums subjektīivi drīzāk tiek interpretēts kā protestu (pret notiekošajiem politiskajiem procesiem un zemas uzticēšanās politikiiem) rezultāts.

Tradicionāli ir pieņemts uzskatīt, ka krievvalodīgo kopienai patriotisma trūkums ir raksturīgāks nekā latviešu kopienai. Tomēr ši pētijuma fokusa

22 Praids - seksuālo minoritāšu pārstāvju organizēts publisks pasākums, lai veicinātu šo marginalizēto grupu tiesību ievērošanu, atbalstītu tās un mazinātu homofobiju un neiecietību. 
grupu interviju rezultāti liecina, ka šāds uzskats neprecīzi ataino reālo situāciju. Krievvalodīgo kopienas pārstāvji, neskatoties uz rūgtumu par politiskajiem procesiem, bieži sevi vienlaikus identificē ar valsti, tiesa, vairāk uztverot teritoriālo piederību un piederību lokālai kopienai.

\section{Lokālā identitāte}

Iedzīvotāji dažādos regionos fokusa grupu interviju laikā norādīja uz piederību noteiktai vietai, reg̣ionam kā nozīmīgu pašidentifikācijas aspektu. Tāpēc subjektīvi uztverti apdraudējumi šajā kontekstā tiek uztverti kā nozīmīgāki. Īpaši tas attiecas uz depopulāciju.

Respondents, L,audona: Latvijas lauku nākotne, Latvijas mazo apdzīvoto vietu izdzìvošana ir loti, l̦oti apdraudēta.

Respondentu diskurss liecina par to, ka lauku iedzìvotāju uztverē Latvijā norisinās divas atškirīgas sabiedriski politiskās dzīves - viena Rīgā, kurai piederīgi viṇi nejūtas, un otra - reǵionos. Reǵionu iedzīvotāji, ìpaši Latgalē, norādījuši arī uz negatīvu attieksmi vai diskriminējošām situācijām, ko izjutuši no Rīgas un Pierīgas iedzīvotājiem. Šāda veida subjektīvās izjūtas paplašina plaisu starp centra un reǵionu iedzīvotājiem.

Respondents, Daugavpils: Mēs viniem esam lauki. Viss, kas ir ärpus Rïgas 30 kilometru attālumā, tie ir lauki.

Fokusa grupas dalībniece, Daugavpils: Esmu saskārusies ar negatìvu attieksmi, jo esmu no Latgales. Latgali, teiksim tā, apspiež. To es esmu izjutusi, pati nē, bet uz bèrniem jā, noteikti.

Šāda subjektīvi uztverta plaisa un atsvešināšanās no valsts pārvaldes regionu iedzīvotājos rada rūgtumu un vilšanos. Turklāt, ņemot vērā fokusa grupām raksturīgos diskursus, secināms, ka atsvešināšanās un vilšanās sajūtai drīzāk ir raksturīgs pieaugums - īpaši reǵionālās reformas dēḷ. Šādas orientācijas var potenciāli negatîvi ietekmēt sabiedrības vienotību un solidaritāti. Tās izgaismo sabiedrības izturētspējas iespējamos vājos posmus, kas krīzes situācijās var negatīvi ietekmēt valsts spēju reageèt uz potenciāliem apdraudējumiem.

\section{Sabiedrības drošība pašvaldībās}

Šajā apakšnodaḷā analizēti pārvaldības rādītāii sabiedrības drošības sektorā trīs Latvijas pašvaldībās - Liepājā, Rēzeknē un Aizkrauklē. Tās ir pašvaldības, kurās draudus sabiedrības drošỉbai fokusa grupu dalïbnieki identificēja kā vienus no trim nozīmīgākajiem draudu veidiem. Katras pašvaldības sniegums tiks analizēts atbilstoši pētījuma gaitā izstrādātai labas pārvaldības matricai. Labas 
pārvaldības rādītāji sabiedrības drošības sektorā analizēti, izmantojot intervijas ar lēmumu pieṇēmējiem pašvaldībās un kvalitatīvo plānošanas dokumentu analīzi (pašvaldību attīstības plānošanas dokumenti, attīstības pārskati un cita publiski pieejama informācija).

\section{Liepājas pilsētas pašvaldība}

Iedzīvotāju etniskais sastāvs Liepājas pilsētas pašvaldībā ir multietnisks. 2018.2019. gadā tika reg̣istrēti "68 945 iedzīvotāji, no kuriem 59\% ir latvieši, 28\% ir krievi, $4 \%$ ir ukraiņi, $3 \%$ ir lietuvieši, $3 \%$ ir baltkrievi un $3 \%$ ir pārējo tautību pārstāvji"23. Šāda diversitāte, kā arī Karostas vēsturiskais mantojums raisa jautājumus par starpetniskajām attiecībām, dažādu etnisko grupu izpratni par apdraudējumiem, ar ko tās sastopas, kā arī pašvaldības spēju reagêèt uz kopienas pārstāvju subjektīvo draudu izjūtu.

Padziḷinātā intervija ar Liepājas pilsētas pašvaldības darbinieku apliecināja, ka vietējās pārvaldes pārstāvji apzinās sabiedrības drošības draudu aktualitāti. Vienlaikus tie netiek identificēti kā prioritāri, salīdzinot ar, piemēram, personiskiem vai politiskiem draudiem. Pašvaldības darbinieks intervijas laikā arī pauda uzskatu, ka, neskatoties uz pastāvošajiem izaicinājumiem, Liepājā nav būtiski apdraudēta nevienas etniskās grupas identitāte un ka visas etniskās grupas spēj mierīgi pastāvēt līdzās, respektējot citu grupu kultūru.

Liepājas pašvaldības pārstāvis: .. mès pilsētā esam spējuši, mācējuši iesaistìt mazākumtautību kopienas, un tās ir kḷuvušas l̦oti lokālpatriotiskas. Jūs neatradīsiet nevienu, kas nav Liepājas patriots. Neatkarīgi no dzimtās valodas, arī krievi. [..] Pilsētā arvien vairāk tiek lietota latviešu valoda. Ja arī pasākums ir krievu valodā, tas tūdal tiek tulkots uz latviešu valodu, ar cieņu un respektu pret valsti un kultūru. ${ }^{24}$

Intervijas laikā pašvaldības pārstāvis arī secināja, ka pašvaldībā nav iespējams runāt par negatīvajām nacionālisma izpausmēm vai izteiktu etniskā vairākuma (latviešu) dominanci. Savukārt kā vienu no sabiedrības drošîbas sektora apdraudējumiem, kas ir aktuāli, respondents norādīja bilingvālās izglīīibas nodrošinājumu Latvijā.

Liepājas pašvaldības pārstāvis: .. tā ir valstiska nolaidība, ka vēl joprojām bērnudārzos nav valsts valoda kā vienīgà apmācību valoda. Tikai tagad vidusskolas gada-publiskais-parskats/

24 Padziḷinātā intervija ar Liepājas pilsētas pašvaldības darbinieku Rīgā, Liepājas pārstāvniecībā, 2020. gada 22. janvārī. 
8.-9. klase pāries uz valodas proporciju par labu valsts valodai. Tā ir nolaidība pēc 30 gadu neatkarības, nolaidība roku rokā ar glèevvulïbu, jo mūs vairāk uztrauc reitingi, nevis valsts attīstība. ${ }^{25}$

Analizējot pastāvošo situāciju sabiedrības drošības kontekstā, cita starpā respondents norādījis arī uz to, ka, viņaprāt, iedzīvotāji vairāk uzticas tieši pašvaldībām, nevis nacionālā līmeṇa valdībai. Sabiedrības uzticēšanos intervējamais cieši saista gan ar to, ka pašvaldībās ir vērojama konsekvence lēmumu pien,emšanas procesos, gan ar to, ka pašvaldỉba ar savu rīcibu mazina apdraudējumus dažāàos drošîbas sektoros.

Liepājas pašvaldības pārstāvis: .. uzticēšanās pašvaldībām Latvijā ir lielāka kā valdībai. Jautājums - kāpēc? Konkrēti Liepājas piemēers parāda iemeslus. Tas ir tädēl, ka varas mainība pašvaldībās ir mazāka nekà centrālās valdības mērogā. Liepājā varas maiña notika pirms gada. Šis izmaiñas, kas arī nenotiek bieži, saglabāja konsekvenci, jo tika respektēti iepriekšējie lèmumi un turpināti iesāktie procesi. [..] Pašvaldību iedzīvotājiem vēelěšanās neinteresē skaistas frāzes, bet interesēe, $k \bar{a}$ tiek renovētas skolas un remontētas ielas, kādas ir personības un kāda ir to reputācija. ${ }^{26}$

Apkopojot intervijas rezultātus, secināms, ka pašvaldības pārstāvja sniegtais vērtējums ir visai optimistisks un neiezīmē būtiskus izaicinājumus sabiedrības drošības sektorā. Tas daḷeji atšḳiras no iedzīvotāju redzējuma, ņemot vērā, ka saskaṇā ar to šāda veida draudi pastāv.

Liepājas pilsētas pašvaldības attīstība saskaņā ar Liepājas domes lēmumu Nr. $1^{27}$ ir nostiprināta divos pašvaldības attīstības plānošanas dokumentos Liepājas pilsētas ilgtspējīgas attīstības stratēgijiā līdz 2030. gadam (turpmāk Stratēóija 2030) un Liepājas pilsētas attīstības programmā 2015.-2020. gadam. Stratēǵijas 2030 virsmērķis ir "stiprināt Liepājas lomu un atpazīstamību starptautiskā mērogā, piesaistot pilsētai zinošus un radošus cilvēkus, investīcijas, tūristus"28. Šì stratēóija tiešā veidā neidentificē apdraudējumus sabiedrības drošībai. Bet tie tiek minēti pastarpināti stratēgijas attīstības virzienā "Liepājnieki un viṇu labklājỉba"29. Šîs prioritātes aprakstā ir apkopotas kultūras un izglīiības apdraudējumu novēršanas rīcíbas. Lìdzịgi kā Stratēgijā

25 Padzị̣inātā intervija ar Liepājas pilsētas pašvaldības darbinieku Rīgā, Liepājas pārstāvniecībā, 2020. gada 22. janvārī.

26 Turpat.

27 Liepājas pilsētas pašvaldība (2015). Domes lēmums Nr. 1. Pieejams: https://www.liepaja.lv/dokumenti/ ?page $=1 \&$ dokumenti_veidi $=$ strategijas

28 Liepājas pilsētas pašvaldība (2017). Liepāja 2030. Pieejams: https://faili.liepaja.lv/liepaja_strategija_ 2030.pdf

29 Turpat. 
2030, Liepājas pilsētas attīstības programmā 2015.-2020. gadam starp aprakstītajām darbības prioritātēm nav tiešā veidā minēta to izaicinājumu novēršana. Tomēr sabiedrības drošības problemātika ir apskatīta pastarpināti, uzskaitot darbības virzienus iespējamo apdraudējumu mazināšanai kultūras un izglīîibas jomā.

No labas pārvaldības perspektīvas raugoties, nav konstatējami trūkumi secības un savstarpējās pamatotības ievērošanā un pašvaldību attīstības plānošanas dokumentu izstrādē sabiedrības drošìbas sektora draudu mazināšanai. Tomēr pētījuma gaitā ir atklājies, ka iespējams konstatēt nepilnības sabiedrības drošības sektora draudu vispārējā/tiešā definēšanā un risku mazināšanas stratēǵiju izstrādē. Netiek identificēti draudi, kas ir saistīti ar grupu identitāti, religiju, izmaiņām kopienas lielumā, ${ }^{30}$ rasismu, nacionālismu un dažādu sabiedrības grupu pārstāvju psiholog̣isko spiedienu.

Izvērtējot normatīvo aktu izmaiṇu izstrādi labas pārvaldības kontekstā, secināms, ka gan dokumentu analīze, gan arī padzị̣inātās, daḷeji strukturētās intervijas ar pašvaldības pārstāvi parāda, ka šis process vērtējams pozitīvi. Izmaiṇas normatīvajos aktos nenotiek bieži, tiek ievērota konsekvence, t. i., rīcība tiek turpināta vai pārcelta no viena normatīvā akta uz otru normatīvo aktu.

Vēl viens nozīmīgs pašvaldības attīstības plānošanas dokuments ir Liepājas pilsētas pašvaldības Uzraudzības ziņojums. Apskatot 2018. gada ziṇojuma attīstības programmas prioritāti "Liepājnieki un viṇu labklājība", iespējams ieraudzìt, ka kultūras un izglìtības apdraudējumi novērsti " $74 \%-90 \%$ apmēră”31. Laika posmā no 2015. gada līdz 2017. gadam veiksmīgi realizētas vairākas prioritāras rīcības, kas saistītas ar sabiedrības drošības stiprināšanu tiešā vai pastarpinātā veidā. Ir vairota pieejamība pirmsskolas izglītības iestādēm, renovētas sporta bāzes un skolas pašvaldības teritorijā, pieaudzis pašvaldības finansējums kultūras aktivitātēm. ${ }^{32}$

Analizējot preventīvo rīcībpolitiku izstrādi sabiedrības drošības kontekstā, var secināt, ka pašvaldībā nav izstrādāta neviena preventīvā rīcíbpolitika, kas veicinātu sabiedrības informètību par to, kā rìkoties, sastopoties ar draudiem, kuri asociējami ar dažādām sabiedrības drošības dimensijām. Līdzịga situācija ir novērojama starpiestāžu koordinācijā. Pašvaldība nav ieviesusi saistošos noteikumus par sabiedrības drošỉbas draudu novēršanu. No tā secināms,

30 Ar izmaiṇām kopienas lielumā tiek saprastas ne vien demogrāfiskas problēmas, bet arī kopienas locekḷu migrācija un iespējamā integrācija.

31 Liepājas pilsētas pašvaldība (2018). Uzraudzības ziņojums par 2018. gadu. Pieejams: https://faili. liepaja.lv/Dokumenti/Dokumentu-biblioteka/Stratēgijas-nozaru-plāni/Uzraudzibas_zinojums_ par_2018_gadu.pdf

32 Turpat. 
ka, iespējams, viens no šāda rīcības trūkuma galvenajiem iemesliem ir fakts, ka pašvaldības pārstāvji nesaskata problēmu, un tāpēc neseko arī rīcība. Tomēr, zinot, ka sabiedrības drošības apdraudējumus iedzīvotāji ir identificējuši, pašvaldības pārstāvjiem nepieciešams pievērst lielāku uzmanību komunikācijai ar vietējās kopienas pārstāvjiem, skaidrojošajam darbam un atgriezeniskās saites saṇemšanai, tādējādi veicinot labāku pārvaldību, kas balstās uz savstarpējo izpratni un koordinētu rīcību. Ne vienmēr tas noteikti nozīmē, ka nepieciešams izdot normatìvos aktus. Ir iespējams rast arī citus risinājumus. Visnozīmīgākā gan ir pašvaldības reakcija uz iedzīvotāju subjektīvo draudu izjūtu un iespēja to mazināt.

\section{Rēzeknes pilsētas pašvaldība}

Rēzeknē iedzīvotāji, līdzīgi kā Liepājā, par nozīmīgiem uzskata sabiedrības drošības sektora draudus. Apskatot Rēzeknes iedzīvotāju etnisko sastāvu, secināms, ka vietējo kopienu veido divas lielas etniskās grupas - latvieši un krievi. Saskaņā ar statistikas datiem 2019. gadā Rēzeknes pilsētas pašvaldībā bija reg̣istrēti 27820 pastāvīgie iedzīvotāji, no kuriem 47\% ir latvieši, 42,5\% krievi, 2,2\% poḷi, 1,4\% baltkrievu, 1,2\% ukraiṇu un 5,6\% citu tautību pārstāvji ${ }^{33}$. No fokusa grupas intervijas rezultātiem, kā arī citiem pētījumiem un aptaujām secināms, ka tieši etniskais sastāvs, etnisko grupu savstarpējās attiecỉbas, kā arī vēsturiskais mantojums ir pamatfaktori, kas ietekmē subjektīvo drošības uztveri pilsētā, tāpēc draudi sabiedrības drošībai ir jāuzskata par nozīmīgiem.

Intervijas rezultāti ar pašvaldības pārstāvi norāda, ka ne tikai iedzīvotāji, bet arī vietējā pašpārvalde apdraudējumus sabiedrības drošỉbai atzīst par svarīgiem. Kā viens no šāda veida draudu determinējošiem faktoriem tika minēts Rēzeknes géogrāfiskais novietojums - tās atrašanās tuvu Krievijas Federācijas robežām. Tiesa, kā draudu avots tika minēta nevis Krievija, bet gan citu Latvijas iedzīvotāju attieksme pret pierobežā dzīvojošajiem.

Intervijas laikā Rēzeknes pilsētas vietējās pārvaldes pārstāvis norādīja, ka nozīmīgākie sabiedrības drošības draudi Rēzeknē ir dažādu etnisko grupu piederības sajūta - piederība Latvijai, reǵionam - Latgalei, kā arī atsevišķu grupu sociālās piederības izjūta. Attiecībā uz kopējo reǵiona piederību Latvijai respondents norādīja, ka pastāv liela atstumtības izjūta, ko izjūt ne tikai Rēzeknes, bet visas Latgales iedzīvotāji. Arī Latgales pārvaldes darbinieki uzskata, ka valstiskā līmenī pastāv dalījums starp Latgali un Latviju. Intervējamais

33 Rēzeknes pilsētas pašvaldība (2019). Rēzeknes pilsētas pašvaldības 2018. gada publiskais pārskats. Pieejams: https://rezekne.lv/wp-content/uploads/2019/06/rezeknes-pilsetas-publiskais-gada-parskats2018.pdf 
norādīja, ka Latvijas sabiedrībā ir daudz cilvēku, kas Latgali skata kā marginalizētu reǵionu ar valsts attīstībai nevēlamām tendencēm.

Rēzeknes pilsētas pašvaldības pārstāvis: Latvija ir normāla, bet Daugavpils un Rèzekne ir nenormāla - tur nedzìvo uzticamas personas, tur cilvēki ir vinu valsts ienaidnieki apriori. [..] Balstoties uz šādiem uzskatiem, notiek mēǵinājumi dalīt Latviju vairākās daḷās. Lai tà saškeltìiba būtu vēl lielāka Latvijā, tiek apgalvots, $k a$ Latgale ir tāda riska vieta, no kuras var sākties kaut kādi apvērsumi. ${ }^{34}$

Apskatot Rēzeknes pilsētas pašvaldības attiecỉbas ar Krievijas valsts un pašvaldību institūcijām, respondents intervijā norādīja, ka pašvaldība kā pārvaldes struktūra veido draudzīgas saiknes, tomēr pašvaldības darbības negūst sabiedrības atbalstu. Rezultātā, viņaprāt, sabiedrībā tiek vairoti mīti par to, ka dzīvot Krievijas tuvumā nozīmē "mīlēt Krieviju un Putinu".

Rēzeknes pašvaldības pārstāvis: Tikai daži cilvēki uzskata, ka tas [Krievijas tuvums un Krievijas realizētā ārpolitika] var apdraudēt viņu drošību. [..] Es domāju, ka šāda veida viedokḷus iespaido tas, ko mēs lasām presē un skatāmies TV, jo tiešā saskarsmē vai personīgas pieredzes [negatīvas pieredzes] nav cilvēkam šajā saistībā. Cilvēks tikai uztver ārējo informāciju, un tad veidojas tāds vai citäds viedoklis. ${ }^{35}$

Interesanti, ka politiskiem draudiem, kas, pēc aptaujātā Rēzeknes pašvaldības pārstāvja uzskatiem, rodas nacionālās valdības un Latgales reǵiona vietējo pašvaldību saspīlēto attiecību rezultātā, viņš saskata tālākas sekas, kas ietekmē citas dzīves sfēras, t. sk. sabiedrības drošību. Intervijas laikā viņš pauda uzskatu, ka nacionālās politikas un nacionāla līmeņa lēmumu pieņēmēju darbības rezultātā veidojas plaisa starp reǵiona iedzīvotājiem un valsti, citu reǵionu iedzīvotājiem un Latgalē dzīvojošajiem.

Rēzeknes pašvaldības pārstāvis: .. nesen tika publicēts pētījums par Daugavpili un Rèzekni. Tajā tika teikts, ka pašvaldība piekopj tādu draudzīgu politiku attiecìbā uz Krieviju, un tas tika traktēts kā nedraudzīga politika attiecībā uz Latviju [ja pašvaldība aktīvi sadarbojas ar Krievijas pierobežu pašvaldībām]. Tie visiem zināmie postulāti - ar kaiminiem visos laikos vajag labāk draudzēties nekā gatavoties karam. Tas būtu pareizais virziens. Bet pētījums bija pasūtìts no valsts puses - tas neveicina [kopīgas piederības sajūtas veidošanu]. Mums ir visādas attiecības. Mēs mēéginām nodibināt labas attiecības ar kaimiņiem, ar pašvaldībām, 
kas nav nekas pretlikumīgs. Ja mēs realizējam kopīgus projektus, izmantojot pārrobežu instrumentus, kas ir noteikts likumos. ${ }^{36}$

Apskatot iedzīvotāju noskaņojumus, pašvaldības pārstāvis norādīja uz Rēzeknes iedzīvotāju, viņaprāt, augsto piederības izjūtu vietējai kopienai, kā arī uz to, ka pašvaldība ir ieguldījusi ievērojamu darbu, lai veicinātu šādu lokālu lojalitāti un atbildīgumu.

Rēzeknes pašvaldības pārstāvis: Jā, sociālā piederība ir loti svarīga, un mums tiek veikti daži pētījumi par šo tēmu. Viss sākas no savas mājas. Es dzīvoju daudzdzīvoklı mājā, un mums ir piederības sajūta pie šìs kopienas kā iedzìvotājam. Tas, protams, ar dažădiem instrumentiem var veidoties - sapulces, kopigi lèmumi, kas tiek pieņemti attiecībā uz savu māju. Parādās soliņ̌s mājas pagalmāan, un tas jau ir moments, ar kuru mēs varam sākt vienas kopienas veidošanu. [..] Mums ir jādzīvo drošībā, un mēs katrs esam atbildīgs par to drošǐbu, nevis nozimēetāa atbildīgā persona. ${ }^{37}$

Intervējot Rēzeknes pašvaldības pārstāvi, uzzinām, ka, līdzīgi kā Liepājā, vietējā līmeņa amatpersonas uz draudiem, kas pastāv sabiedrības drošîbas sektorā, skatās daudz optimistiskāk nekā iedzīvotāji. Iespējams, ka šāds optimistisks skatījums ir viens no nozīmīgākajiem iemesliem, kāpēc pašvaldības attīstības plānošanas dokumentos nav atrodams draudu novērtējums un atbilstošu risinājumu meklējumi.

Pašvaldības attīstības plānošanas dokumentos - Rēzeknes pilsētas ilgtspējīgas attīstības stratēgijā līdz 2030. gadam, Rēzeknes pilsētas attīstības programmā 2014.-2020. gadam un Rēzeknes pilsētas pašvaldības jaunatnes politikas plānošanas dokumentā 2020.-230. gadam ${ }^{38}$ - sabiedrības drošības draudi tiek minēti pastarpināti. Tomēr, atšķirībā no Liepājas pilsētas pašvaldības attīstības plānošanas dokumentiem, Rēzeknes pašvaldība uzsver nepieciešamību stiprināt "latgaliešu kultūru, vērtības un tradīcijas, kas balstās valodā, ražošanā un izdevīgā geogrāfiskā novietojumā"39.

Raugoties no labas pārvaldes perspektīvas, visas trīs analizētās rīcíbpolitikas stratēǵijas ir savstarpēji pamatotas un iesaistītas pašvaldības attīstības plānošanas dokumentu izstrādē. Darbības, kas ir iekḷautas pašvaldības attīstības

36 Padziḷinātā, daḷēji strukturētā intervija ar Rēzeknes pilsētas pašvaldības pārstāvi Rēzeknē 2020. gada 21. janvārī.

37 Turpat.

38 Rēzeknes pilsētas pašvaldība (2020). Pilsētas plānošanas dokumenti. Pieejams: https://rezekne.lv/ pilsetas-attistibas-dokumenti/

39 Rēzeknes pilsētas dome (2014). Rēzeknes pilsētas ilgtspējīgas attīstības stratēǵija 2030. Pieejams: https://rezekne.lv/wp-content/uploads/2017/08/rezeknes-pilsetas-ilgtspejigas-attistibas-strategijalidz-2030-gadam.pdf 
plānošanas dokumentos, ir secīgas un pamatotas, ir ievērots pēctecības princips. Savukārt, vērtējot praktisko pienesumu, secināms, ka konstatējamas nepilnības sabiedrības drošības sektora draudu definēšanā un iekḷaušanā rīcībpolitikās. Nav ietverti virzienrādītāji sabiedrības drošības draudu mazināšanā, nav arī skaidrs, kā, īstenojot pasākumu kopumu, kas ir iekḷauts pašvaldības attīstības plānošanas dokumentos, ${ }^{40,}{ }^{41}$ tiks mazināta plaisa piederības veicināšanā starp mēs - Latvija $v s$ jūs - Latgale. Nav noteikti rīcības virzieni un rezultativitātes rādītāji.

Apskatot preventīvo rīcībpolitiku izstrādi, secināms, ka pašvaldībā nav izstrādāta neviena preventīvā rīcībpolitika, kuras mērḳis būtu informēt sabiedrību par rīcību, reagéjot uz sabiedrības drošības draudiem. Papildus, saskaņā ar publiski pieejamo informāciju, Rēzeknes pilsētas pašvaldībā nav izstrādāts atsevišḳs civilās aizsardzības plāns. Civilā aizsardzības plāna funkciju pašvaldībā pilda izstrādātais Rēzeknes pilsētas teritorijas plānojums 2018.-2030. gadam, ${ }^{42}$ kurā iekḷauta informācija par stratēgiski nozīmīgiem objektiem pašvaldībā, un vides pārskats, ${ }^{43}$ kas ir šis rīcībpolitikas neatṇemama sastāvdaḷa. Informācija par sabiedrības drošības apdraudējumu un rīcỉbas virzieniem to mazināšanai šajos dokumentos nav iekḷauta. Izvērtējot starpiestāžu koordināciju, secināms, ka tā tiek īstenota daliēji. ${ }^{44}$

40 Analizējot Rēzeknes pilsētas plānošanas dokumentus, pētījumā tika secināts, ka "Rēzeknes pilsētas ilgtspējīgas attīstības stratēǵijas 2030” (turpmāk arī - Stratēǵija 2030) vīzija ir cieši saistīta ar rēzekniešu kultūras un tradīciju stiprināšanu. Stratēgijā divi rīcības virzieni - "Sekmēt Rēzeknes kā Austrumlatvijas izglītības, pētniecības un sporta centra attīstību"; "Veidot Rēzekni kā cilvēkam un videi draudzīgu, drošu un mūsdienīgu pilsētu Eiropas Savienības Austrumu pierobežā” - pastarpināti definē sabiedrības drošības sektora draudus, kas ir saistīti ar izglītības kvalitātes celšanu, kultūras un etniskās daudzveidības saglabāšanu, stiprinot sabiedrības integrāciju. Attīstības programmas 2014.-2020. gadam viens no darbības virzieniem ir kvalitatīvas dzīves telpas nodrošināšana pilsētas iedzīvotājiem. Pastarpinātā veidā šis darbības virziens iezīmē potenciālos draudus sabiedrības drošībā. Saskaṇā ar SVID (SVID - stiprās puses, vājās puses, iespējas, draudi) analīzi, kas tika iekḷauta attīstības programmā, potenciālie draudi ir sasaistes trūkums starp dažādiem plānošanas līmeņiem un nepietiekams kultūras pasākumu apmeklētāju skaits (tāpēc mazināsies piederība Latvijas kultūrai). Jaunatnes politikas pamatnostādnes, atškirīibā no Stratēǵijas 2030 un attīstības programmas, iekḷauj rezultativitātes rādītājus. Viens no tās darbības virzieniem ir cieši saistīts ar jauniešu integrāciju un piederības sajūtas stiprināšanu Latvijai.

${ }^{41}$ Rēzeknes pilsētas dome (2014). Rēzeknes pilsētas ilgtspējīgas attīstības stratēǵija 2030. Pieejams: https://rezekne.lv/wp-content/uploads/2017/08/rezeknes-pilsetas-ilgtspejigas-attistibas-strategijalidz-2030-gadam.pdf; Rēzeknes pilsētas dome (2020). Rēzeknes pilsētas jaunatnes politikas attīstības programma 2020.-2023. gadam. Pieejams: https://rezekne.lv/wp-content/uploads/2020/05/1198_ jaunatnes-strategija-2020-2023.pdf

42 Metrium (2017). Rēzeknes pilsētas teritorijas plānojums 2018.-2030. gadam. Pieejams: https:// rezekne.lv/wp-content/uploads/2018/04/paskaidrojuma_raksts.pdf

43 Turpat.

44 Starpiestāžu koordinācijas daḷēja īstenošana tika konstatēta, analizējot jaunatnes politikas attīstības programmu, kurā bija skaidrs, definēts atbildīgo iestāžu loks. 


\section{Aizkraukles novada pašvaldība}

Aizkrauklē veiktās fokusa grupas intervijas rezultāti norādīja uz to, ka arī šajā pilsētā iedzīvotāji sabiedrības drošỉbas draudus uzskata par nozīmīgiem. Saskaṇā ar Centrālās statistikas pārvaldes datiem Aizkraukles novadā 2018. gadā bija reǵistrēti 8687 iedzīvotāji, no tiem - 68,3\% latvieši, 21,2\% krievi, 3,2\% baltkrievi, 2,3\% ukraini,i, 1,5\% poḷi un 3,6\% pārējie ${ }^{45}$. No etniskā izkārtojuma redzams, ka, lai arī kopumā vietējā kopiena raksturojama kā multietniska, pastāv vienas etniskās grupas dominance. Tomēr intervijas laikā pašvaldības pārstāvis norādīja, ka dominējošā loma lokālās identitātes veidošanā Aizkrauklē ir nevis etnisko īpatnību izjūtai, bet gan piederības izjūtai savai pilsētai. Tas gan neesot, viņaprāt, stipri izteikts, jo lielākā daḷa iedzīvotāju ir iebraucēji. ${ }^{46}$

Aizkraukles novada pašvaldības pārstāvis: Aizkrauklē nav izteikta kādas etniskās grupas dominēšana. Visi sadzìvo mierīgi un respektē viens otru. [..] Kā jau mazā pilsētā, visi visus pazīst. ${ }^{47}$

Intervijas laikā respondents arī norādīja uz Aizkraukles vēsturisko mantojumu ${ }^{48}$ un tā saglabāšanu iedzīvotāju vēsturiskajā atmiņā, kas, viņaprāt, ir viens no nozīmīgākajiem aspektiem sabiedrības drošības kontekstā. Respondents norādīja, ka šādas kolektīvās vēsturiskās atmiņas trūkums liecina par to, ka trūkst sajūtas, ka piederi pie vietējās kopienas.

Salīdzinājumā ar citām analizētajām pašvaldībām Aizkraukles novada pašvaldībā ir izstrādāti vairāki attīstības plānošanas dokumenti - Aizkraukles novada ilgtspējīgas attīstības stratēǵija 2014.-2025. gadam, Energettikas rīcības plāns, Aizkraukles novada Daugavas ūdenskrātuves ainavu koncepcija, Aizkraukles novada teritorijas plānojums 2014.-2026. gadam, Aizkraukles novada ilgtspējīgas attīstības programma 2014.-2020. gadam. ${ }^{49}$ Tomēr, analizējot kvalitatīvos dokumentus, tika secināts, ka tikai divos no tiem pastarpinātā veidā definēti rīcības virzieni sabiedrības drošǐbas sektora draudu mazināšanai. Atšķirībā no Rēzeknes un Liepājas attīstības dokumentiem, Aizkrauklē nevienā plānošanas dokumentā nav uzsvērta nepieciešamība stiprināt piederības sajūtu pašvaldỉbai.

45 Aizkraukles novada dome (2019). Publiskais pārskats par 2018. gadu. Pieejams: http://www. aizkraukle.lv/wp-content/uploads/2019/09/29.08.2019._217_Publiskais_pārskats.pdf

46 Padziļinātā intervija ar Aizkraukles novada pašvaldības darbinieku 2020. gadā.

47 Turpat.

48 Aizkraukle kā energètiķu pilsēta Padomju Savienības laikā.

49 Aizkraukles novada pašvaldība (2020). Attīstības plānošanas dokumenti. Pieejams: http://www. aizkraukle.lv/lv/pasvaldiba/attistibas-planosanas-dokumenti/attistibas-programma/ 
No labas pārvaldības principu ieviešanas perspektīvas raugoties, secināms, ka visas analizētās rīcibpolitikas ir savstarpēji pamatotas. To izstrādē ir vērojama pēctecỉba un konsekvence. Līdzīgi kā Rēzeknes un Liepājas pilsētu pašvaldību gadījumā, arī Aizkraukles novada pašvaldības plānošanas dokumentos konstatējamas nepilnības sabiedrības drošības sektora draudu definēšanā un to integrācijā rīcibpolitikas iniciatīvās. Atšķirīibā no Liepājas, kurā ir izstrādāts civilās aizsardzības plāns, un Rēzeknes, kurā civilās aizsardzības plāns ir daļa no vides pārskata, Aizkrauklē ir nodibināta Aizkraukles sadarbības teritorijas civilās aizsardzības komisija un 2018. gadā apstiprināts tās darbības nolikums. Nolikumā atrunāts komisijas sastāvs, funkcijas un apziṇošanas kārtība krīzes situācijās. Saskaņā ar to notiek apziṇošanas kārtības pārbaudes divas reizes gadā..$^{50}$ Tomēr, līdzīgi kā citās analizētajās pašvaldībās, Aizkraukles sadarbības teritorijas civilās aizsardzības komisija neaktualizē sabiedrības drošības draudus, kas arī nav ne pārsteidzoši, ne nepareizi. Civilās aizsardzības plānam ir citi mērķi un sabiedrības drošības apdraudējumi, kā arī to novēršanas mehānismi atrunājami citos dokumentos. Tiesa, aplūkojot citus publiski pieejamus normatīvos aktus, secināms, ka sabiedrības informētîba par to, kā rīkoties, sastopoties ar sabiedrības drošîbas apdraudējumiem, veicināta drīzāk netiek. Līdzīgi kā citās pašvaldībās, Aizkraukles novadā nav izstrādāta atbilstoša rīcībpolitika.

Apkopojot iegūtos datus par visām pašvaldībām, var secināt, ka pašvaldības un lēmumu pieņēmēji identificē sabiedrības drošības sektora draudus. Un, lai arī lēmumu pieņēmēju un pašvaldības iedzìvotāju skatījums uz sabiedrības drošību nav krasi atšķirīgs, tomēr atšķiras skatījums uz šo draudu intensitātes pakāpi. Pašvaldības plānošanas dokumentu analīze atklāj, ka reakcija uz sabiedrības drošibas apdraudējumiem ir visai ierobežota un nepilnīga.

Analizējot pašvaldību reakcijas uz sabiedrības drošỉbas sektora draudiem un izmantojot labas pārvaldības matricu, nākas secināt, ka, no vienas puses, visās trijās analizētajās pašvaldībās ir nodrošināta pārvaldības sistēmas stabilitāte un ilgtermiṇa plānošanas redzējums, pieṇemtās rīcībpolitikas ir pamatotas un secīgas. Tomēr šis redzējums par sabiedrības drošības sektoru ir drīzāk nepilnīgi atrunāts plānošanas dokumentos. Tajos draudi sabiedrības drošībai tiek identificēti pastarpināti.

Attiecībā uz caurskatāmību kā labas pārvaldības indikatoru secināms, ka Liepājas un Rēzeknes pilsētas un Aizkraukles novada pašvaldībās lēmumu 
pieṇemšanas process ir caurskatāms. To nosaka likuma "Par pašvaldībām" 26. pants, atrunājot, ka "domes sēdes ir atklātas, ja likumos nav noteikts citādi. [..] Domes lēmumi un domes sēžu protokoli ir publiski pieejami" ${ }^{2}$. Visi pieṇemtie domes lēmumi ir publiski pieejami visās pašvaldību mājaslapās. Tas veicina caurskatāmību un informācijas pieejamību. Turklāt visās analizētajās pašvaldībās tiek izmantoti alternatīvie sabiedrības informēšanas kanāli - pilsētas/novada avīzes, mājaslapas un sociālie tīkli.

Analizējot normatīvo aktu izmaiņu biežumu, secināms, ka nevienā analizējamā pašvaldībā nav novērojamas pašvaldības normatīvo aktu dinamiskas vai krasas, neprognozējamas izmaiņas. Tas vērtējams pozitīivi. Bet, izvērtējot ierēdṇu profesionalitāti, pētījuma gaitā tika ṇemti vērā starptautiski atzīta InCiSE indeksa (International Civil Service Effectiveness (InCiSE) Index, starptautisks ierēdṇu efektivitātes indekss) dati, kur Latvija gan centrālā pārvaldes līmenī, gan pašvaldību līmenī tiek atzinīgi novērtēta un ierindota 23 . vietā. ${ }^{53}$ Tas, no vienas puses, uzskatāms par pozitīvu rādītāju, tomēr, no otras, joprojām norāda uz nepieciešamību pēc izaugsmes.

Attiecībā uz sabiedrības informētỉbu par iespējamiem rīcības modeliem, sastopoties ar sabiedrības drošības draudiem, secināms, ka visās analizētajās pašvaldībās - Rēzeknē, Liepājā un Aizkraukles novadā - tika identificēta šì labas pārvaldes kritērija nepietiekama izpilde. Nevienā analizētajā pašvaldībā nav izstrādātas konkrētas vadlīnijas, kā var atpazìt un kā būtu jārīkojas, sastopoties ar sabiedrības drošîbas draudiem, kā arī nav viennozīmīgi vērtējama starpiestāžu koordinācijas spēja. Konkrēts rīcības plāns ar pasākumiem sabiedrības drošỉbas apdraudējumu mazināšanai daļēji tika īstenots tikai Rēzeknes pilsētas pašvaldībā. Citās pašvaldībās šādu rīcības plānu izstrāde netika konstatēta. Lai arī ne vienmēr jaunu rīcībpolitikas dokumentu izstrāde ir vienīgais cel̦š problēmas risināšanā un arī šajā gadījumā, iespējams, tas nav obligāts priekšnosacījums iedzīvotāju subjektīvās draudu uztveres mazināšanai, tomēr ir arī citi faktori, kas norāda uz pašvaldību nepietiekamo uzmanību šim draudu veidam. Intervijas ar pašvaldību pārstāvjiem apliecina, ka iemesls, kāpēc plānošanas dokumentos netiek minēti sabiedrības drošības draudi, drīzāk ir nepietiekama draudu aktualitātes izpratne, nevis tas, ka ir praktiski risinājumi to mazināšanai.

51 Latvijas Republikas Saeima (1994). Likums “Par pašvaldībām”. Pieṇemts 19.05.1994. Spēkā no 09.06.1994. Pieejams: https://likumi.lv/ta/id/57255-par-pasvaldibam

52 Turpat.

53 Blavatnik school of Government, Oxford University (2019). International Civil Service Effectiveness Index, p. 79. 
Otrs būtisks aspekts - sabiedrības drošỉbas izpratne neattiecas tikai uz etnisko sadalījumu un etniskās identitātes saglabāšanu. Tā var tikt attiecināta arī uz reliǵisko piederību un citiem sociālās identitātes aspektiem. Problēma ir tā, ka gan vietējo kopienu locekḷi, gan arī pašvaldību pārstāvji galveno uzmanību pievērš etniskai identitātei un tās iespējamai ietekmei uz piederības sajūtu valstij un meklē risinājumus, kā veicināt piederības sajūtu konkrētai vietai - pašvaldības teritorijai. Tomēr, pirmkārt, piederības veicināšana kādai konkrētai vietai vai lokālai kopienai ne vienmēr veicina piederības izjūtu valstij. Otrkārt, sabiedrībā visos līmeņos joprojām noklusēti un neizdiskutēti paliek jautājumi par citām identitātēm un cita veida sociālo grupu drošîbu un iekḷaušanos sabiedrībā.

\section{Secinājumi}

Pētijuma rezultāti sabiedrības drošības sektorā atklāj, ka Latvijas iedzīvotāji identificē draudus to unikālajai patîbai un atzīst tos kā būtiskus izaicinājumus savai drošībai. Visbiežāk respondentus satrauc imigrācija un, viṇuprāt, līdz ar to nenovēršama nacionālās identitātes zaudēšana. İpaši Latvijas iedzīvotājus biedē potenciālie migrācijas viḷni no musulmaṇu valstīm. Musulmaņi tiek uztverti kā nozīmīgs svešais. Rezultātā secināms, ka Latvijas sabiedrībai kopumā - neatkarīgi no iedzīvotāju izvietojuma pilsētās vai lauku apvidos, to izglītîbas pakāpes vai sociālā statusa - ir raksturīga neuzticēšanās un izteikti aizspriedumi pret islāmticīgajiem vai jebkuriem citiem svešu kultūru pārstāvjiem, vai pret jebko citu, kas būtiski atškiras no tradicionālajiem uzskatiem par indivīdam atbilstošu uzvedību, gimenes modeli vai sabiedrības funkcionēšanu.

Analizējot negatīvās attieksmes pret atšķirīgo Latvijas sabiedrībā, t. sk., piemēram, pret seksuālajām minoritātēm, secināms, ka tā ir orientēta uz tradicionālām vērtībām, drīzāk slēgta sabiedrība, kas atšḳirīgo uztver kā nopietnu apdraudējumu nācijas izdzīvošanai. Rezultātā minoritāšu grupas tiek marginalizētas, izjūt nozīmīgu psiholog̣isku spiedienu un to jebkāda veida pārstāvniecibai dominējošā sabiedrības daḷa liek ievērojamus šķērš̌lus.

Klaji negatīvā attieksme pret atšķirīgo vieno citkārt savstarpēji nošķirtās latviešu un krievvalodīgo kopienas. Šo kopienu pārstāvji atzīst savstarpējo nošķīrumu un lūkojas ar aizdomām uz pretējās puses pārstāvjiem, tomēr šķelšanos pēc lingvistiskās piederības tie reti uzskata par nozīmīgākajiem draudiem savai drošībai. Drīzāk tas tiek skatīts kā kaut kas sekundārs vai potenciāli bīstams nākotnē nelabvēlīgu valsts attīstības scenāriju vai konfliktu gadījumā. 
Izceḷams ir iedzīvotāju negatīvais patriotisma vērtējums. Intervijas atklāj, ka daḷa sabiedrības patriotisma trūkumu saredz kā nopietnu izaicinājumu valstij. Tomēr, izzinot tuvāk iedzīvotāju uzskatus, biežāk ar to tika asociēts uzticēšanās trūkums Latvijas valdībai un valsts pārvaldes institūcijām, atsvešināšanās no politiskās varas. Nedaudz atšķirīga situācija ir dạ̦ā krievvalodīgo kopienu, kas politisko režīmu saskata kā tai naidīgu un subjektīvi uztver psiholoğisku spiedienu.

Runājot par atsvešināšanos no politiskās varas, īpaši atzīmējama arī Latvijas regionu subjektīivi uztvertā plaisa starp Rīgu un reǵiona iedzīvotājiem. Tiek uzsvērts, ka pastāv divas atšķirīgas sabiedriski politiskās dienaskārtības. Viena Rīgā, otra - reǵionos. Rezultātā reǵionu iedzīvotāji izjūt ne tikai psihologisku spiedienu un subjektīvi vērtē to kā diskrimināciju, bet arī nopietnas bažas par lokālo kopienu izdzīvošanas iespējām. Šāda veida bailes būtiski negatīvi ietekmē Latvijas sabiedrības vienotību un solidaritāti.

Kā nozīmīgākos iekšêjos apdraudējuma avotus sabiedrības drošības sektorā Latvijas iedzīvotāji nosaukuši citu valstu iedzīvotājus (iebraucējus) vai to grupas, kā arī valsts pārvaldes iestādes, bet ne pašvaldības. Pašvaldības arī šajā jomā bauda iedzīvotāju lielāku uzticēšanos. Pa nozīmīgāko ārējo draudu avotu sabiedrības drošībai iedzīvotāji uzskata Krievijas Federāciju, uzsverot tās iespējas negatīvi ietekmēt sabiedrības stabilitāti.

Padzilịnātās intervijas ar pašvaldību pārstāvjiem atklāj, ka tie galvenokārt atpazīst sabiedrības drošības draudus, tomēr saredz minimālu pašvaldības lomu vai to nesaredz vispār drošības stiprināšanā šajā jomā, jo uzskata, ka tas ir nacionālā pārvaldes līmeņa institūciju pienākums. Tiesa, pašvaldību ikdienas prakses pierāda, ka bieži vien tiek sniegts zināms ieguldījums vietējo kopienu stiprināšanā, etnisko minoritāšu patības saglabāšanā un citās aktivitātēs sabiedrības drošỉbas pilnveidē. Tas liecina par to, ka trūkst vienotas izpratnes par sabiedrības drošỉbas daudzdimensionālo dabu un savstarpējām cēloṇsakarībām starp kultūras īpatnību saglabāšanu un nacionālās izturētspējas stiprināšanu.

Pētỉjuma rezultāti arī norāda uz to, ka pastāv plaisa starp nacionālā un vietējā līmeņa pārvaldes institūcijām. Šis un arī citi faktori nosaka to, ka vietējā līmeņa pārvaldes institūcijas bieži vien savu neizdarību, pieņemot lēmumus sabiedrības drošības stiprināšanai, pamato ar to, ka tas ir nevis pašvaldību, bet gan nacionālā līmeṇa pārvaldes institūciju pienākums. Tomēr tā gluži nav. Bieži vien sabiedrības drošǐbas draudu mazināšana ir tieši saistìta nevis ar nacionālā līmeņa institūciju kompetencēm, bet gan tieši ar pašvaldību kompetencēm. Jāatzīst, ka nav novērojama arī interese par abu - nacionālā un lokālā līmeņu sadarbību iedzīvotāju draudu uztveres mazināšanai. Tāpēc iedzīvotāji 
netiek sadzirdēti un sabiedrības drošỉbas sektorā netiek sperti soḷi identificēto apdraudējumu mazināšanā. Ieteicams veicināt gan ciešāku mijiedarbību ar iedzīvotājiem, lai apzinātu tiem aktuālos apdraudējumus un atbilstoši reageètu, gan arī lokālā un nacionālā mēroga institūciju sadarbību reaǵěšanas mehānismu izstrādē.

Vēl viens nozīmīgs aspekts, kam nepieciešams pievērst uzmanību, ir patriotisma jautājums. Lai arī nacionālā un vietējā mērogā pārvaldes institūcijas veic ievērojamu darbu patriotisma izjūtas stiprināšanā, tomēr iedzīvotāju apdraudējuma subjektīvo uztveri, iespējams, varētu mazināt vēl papildu informatīvie pasākumi un pasākumi pilsoniskās iesaistes veicināšanai pašvaldībās. Pilsoniskā iesaiste paredz ne tikai sabiedrības informēšanu par dažādām pilsoniskās iesaistes formām pašvaldībā, bet arī NVO un interešu grupu atbalstu. To darbība ir orientēta uz pilsonisko audzināšanu. Ir svarīgi, lai pilsoniskā iesaiste veicinātu visu grupu iekḷaušanu, nevis kādas grupas izslēgšanu vai identitātes apdraudēšanu. 